\title{
Karyotype-phenotype Correlations in Gonadal Dysgenesis and Their Bearing on the Pathogenesis of Malformations
}

\author{
MALCOLM A. FERGUSON-SMITH
}

\author{
From the Department of Genetics, University of Glasgow
}

Turner's syndrome was originally described as a disorder of adult women characterized by infantilism, congenital webbed neck, and cubitus valgus (Turner, 1938). It was later shown that the important pathological defect was the absence of normal ovaries which are invariably replaced by thin white 'streaks' of ovarian stroma without follicles (Wilkins and Fleischmann, 1944). With the accumulation of clinical experience, the criteria for inclusion in the syndrome have become modified and enlarged, so that Turner's syndrome can now be defined more accurately as a disorder of women in which short stature, infantilism, streak gonads, and associated congenital malformations are the four cardinal features. The associated malformations are so characteristic that it is useful to refer to them as 'Turner stigmata'. They include shield chest, webbing of the neck, peripheral lymphoedema at birth, short IVth metacarpals, hypoplastic nails, multiple pigmented naevi, and coarctation of the aorta (Haddad and Wilkins, I959).

A number of patients have been observed who have many features in common with Turner's syndrome, but who do not qualify for the complete syndrome on these criteria because they lack one or more of the cardinal features. Thus, some patients are of normal stature, some have secondary amenorrhoea, some are without Turner stigmata, and some show masculinization. These patients may be referred to as variants of Turner's syndrome.

In 1954 it was shown that many patients with Turner's syndrome have chromatin-negative nuclear sex (Polani, Hunter, and Lennox, 1954), and five years later the explanation of this anomaly was provided by the demonstration of an XO sex chromosome constitution in a typical patient (Ford, Jones, Polani, de Almeida, and Briggs, 1959). However,

Received November 23, 1964. other patients were soon found who had chromatin- ? positive nuclear sex and different types of abnormal $\overrightarrow{\vec{N}}$ sex chromosome constitutions, including structural ${ }^{N}$ $\mathrm{X}$ chromosome aberrations, and various types of sex chromosome mosaicism. This experience $\vec{c}$ raised the possibility that if the classical case of Turner's syndrome were the result of monosomy for $\Phi$ the $\mathrm{X}$ chromosome, perhaps variants of Turner's $\vec{\theta}$ syndrome could be explained on the basis of vari- of able deficiency of the sex chromosomes intermediate between $\mathrm{XO}$ and $\mathrm{XX}$, and $\mathrm{XO}$ and $\mathrm{XY}$ (see, for example, Griboff and Lawrence, I96I; Ford, 1963).

Observations on 30 female patients with abnormal $\frac{0}{\circ}$ gonadal development (gonadal dysgenesis) seen at $\cong$ Johns Hopkins Hospital (Ferguson-Smith, Alex- $\stackrel{\vec{O}}{\overrightarrow{3}}$ ander, Bowen, Goodman, Kaufmann, Jones, and Heller, I964a) not only confirm this view, but suggest that the complete Turner's syndrome is due to monosomy of loci in the short arm of the $\mathrm{X} \overline{\overline{3}}$ chromosome, which are homologous with loci in the $\mathrm{Y}$ chromosome. This hypothesis explains the 3 observation that short stature and Turner stigmata may result from deletions in either the $X$ or $Y \stackrel{\circ}{3}$ chromosome. It also postulates that many of the clinical variants of Turner's syndrome occur as a result of variable deficiency of the sex chromosomes $\frac{7}{0}$ due to sex chromosome mosaicism, in which some somatic cell lines have normal XX or XY comple- $N$ ments while others have deficient sex chromosome complements.

This paper attempts to test this hypothesis by $\omega$ reviewing the available reports on chromosome analysis in gonadal dysgenesis. 307 cases have been classified according to their sex chromosome $\Phi_{\overparen{D}}$ constitution, so that the relationships between the ${ }^{+}$ clinical and chromosomal findings may be assessed $\frac{T}{T}$ for each class. As a result, some interesting corre- $\frac{\vec{O}}{\mathbb{D}}$ lations between karyotype and phenotype have $\stackrel{\mathbb{Q}}{\mathbb{Q}}$ emerged, which strengthen the above hypothesis, $\stackrel{\mathbb{2}}{0}$ 
and have a bearing on the pathogenesis of other types of abnormal gonadal development. The karyotype-phenotype correlations also indicate that genetic inactivation of one $\mathrm{X}$ chromosome in female somatic cells does not extend to all loci on that chromosome.

\section{Materials and Methods}

By convention, the term gonadal dysgenesis has become restricted to Turner's syndrome and its variants, though it might be correctly applied to all cases of abnormal gonadal development. The convention is followed here, so that disorders such as Klinefelter's syndrome and true hermaphroditism are excluded. Patients with almost all other types of abnormal gonadal development associated with sex chromosome aberrations, or of unknown aetiology, are included where adequate clinical descriptions and karyotype analyses are available.

Clinical information (as indicated in Table I) concerning the stature, presence or absence of Turner stigmata, the type of sex differentiation, the presence of severe mental defect, and the parental ages. at the birth of the patient, were sought from each case history, and these data were augmented in certain cases by personal communication with the authors. The presence or absence of the characteristic in question (such as short stature) was accepted according to each author's definition, though individual authors seemed to differ slightly in their criteria, particularly where the characteristic was difficult to measure (e.g. webbing of the neck). Many of the reports fail to record negative findings in respect of the less striking Turner stigmata (such as hypoplasia of the nails). Thus, in Table I the frequencies recorded for each characteristic are likely to be higher than the actual frequencies.

As most of the patients included in this review have been selected for study on the basis of clinical criteria, ascertainment bias must be borne in mind in the interpretation of karyotype-phenotype correlations. This difficulty appears unavoidable, because an unselected series of cases could only be obtained by chromosome analysis of large samples of the general population. (The magnitude of this task is easily appreciated when one considers that, on average, over 2,500 people would have to be tested in order to detect a single XO case of gonadal dysgenesis.) However, using the material at present available, realistic karyotype-phenotype correlations can safely be made on characteristics, such as parental age, that have played little or no part in the selection of cases. On the other hand, the data cannot be used to estimate, for example, the prevalence of the various karyotype categories, or the frequency of a particular malformation in any one karyotype category. With characteristics which have been important in the selection of a proportion of cases, correlations between karyotype and phenotype may be meaningful if the part played by selection is taken into account. For example, though many patients have been selected on account of short stature, $20 \%$ of $\mathrm{XO} / \mathrm{XX}$ mosaic cases are within the normal range of height, whereas all XO cases are short; the correlation between the presence of normal $\mathrm{XX}$ cell lines and normal height in these patients is clear.

It therefore seems relevant to consider the various methods used in the ascertainment of patients in the present study, and the effect these methods have on karyotype-phenotype correlations. In the two large series of de la Chapelle (1962) and Lindsten (1963), patients are selected by very strict clinical criteria, so that only those with the complete Turner's syndrome are included. Clinical differences between the various karyotype categories thus tend to be minimal, some karyotype categories are not observed (e.g. $\mathrm{XO} / \mathrm{XY}$ ), and karyotype-phenotype correlations are not as informative as in other series which have been selected on less rigid grounds. Jacobs, Harnden, Buckton, Court Brown, King, McBride, MacGregor, and Maclean (I96I) describe a series of patients selected initially because of primary amenorrhoea, and Ferguson-Smith et al. (I964a) selected their patients because each had at least one of the principal features of Turner's syndrome. Although the former series excludes patients with gonadal dysgenesis and secondary amenorrhoea, and both series exclude those (if any) with a normal phenotype associated with a sex chromosome abnormality, meaningful karyotype-phenotype correlations are noted in each study.

Sex chromatin studies have provided another source of patients with gonadal dysgenesis (e.g. Maclean, Harnden, Court-Brown, Bond, and Mantle, 1964), but here the selection is again incomplete, as the method detects only persons in whom there is a discrepancy between the nuclear sex and the sex of rearing. The advantage of the method is that there can be no argument against comparing clinical findings in the karyotype categories that are detected. Unfortunately, only a few cases have been detected by this method so that its full possibilities are still to be realized.

The literature also records smaller series of patients with gonadal dysgenesis, and numerous single cases. Some are published on account of the rare nature of the chromosome aberration, or because of bizarre clinical findings. Up to the time of writing over 300 reported cases of gonadal dysgenesis with adequate clinical descriptions and karyotype analyses could be found, and undoubtedly others have been overlooked. It has been considered neither practical nor appropriate to list the findings in each case separately, but references are given in Table II.

\section{Results}

Most of the patients reviewed can be grouped by their sex chromosome constitutions into I of the 15 karyotype categories shown in Table I (see key to karyotype symbols). The frequency of short stature and of each of the seven major Turner stigmata, and the type of sex differentiation observed are noted for each of these karyotype categories. Table I also includes the frequency of severe mental 


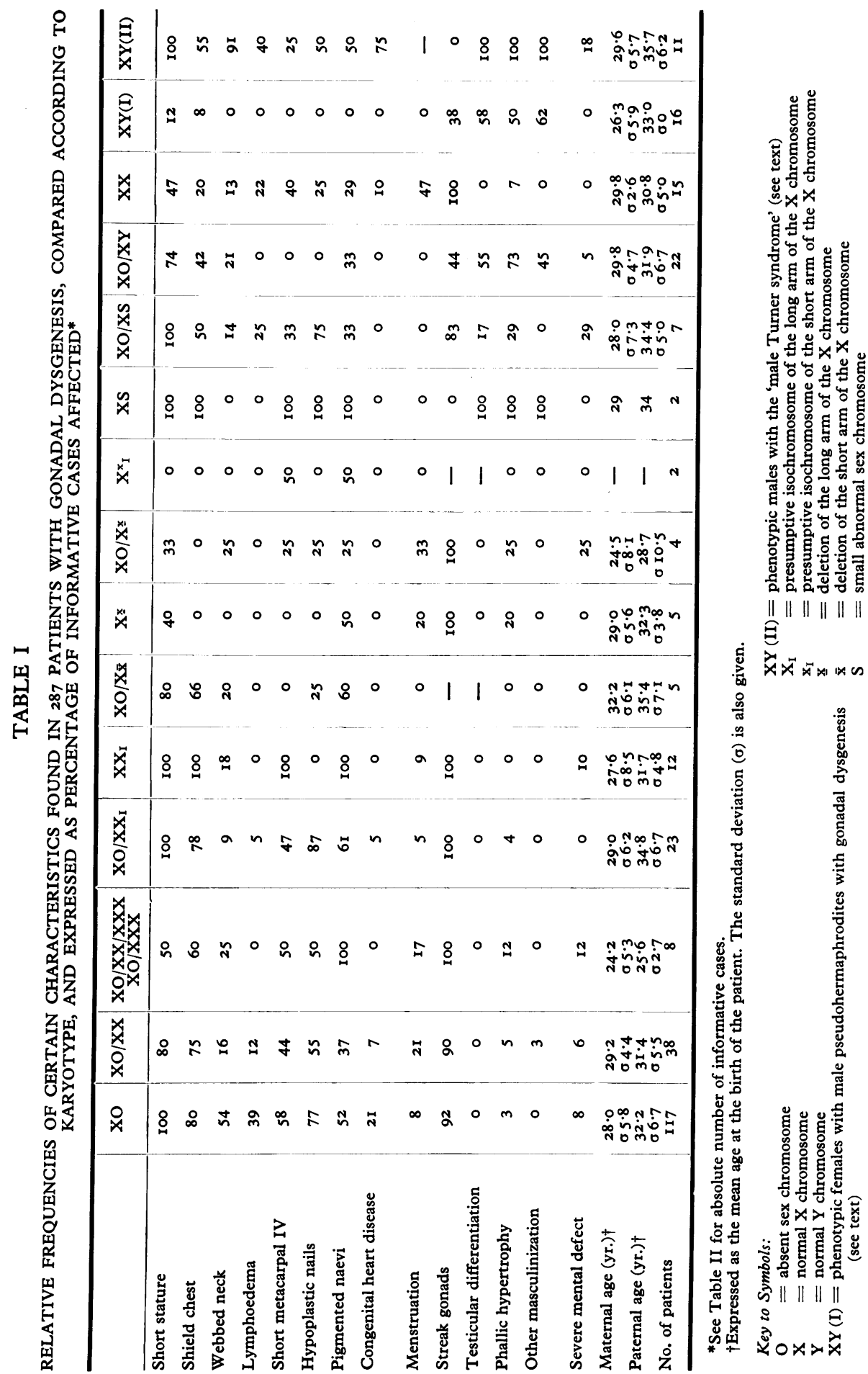


Karyotype-phenotype Correlations in Gonadal Dysgenesis

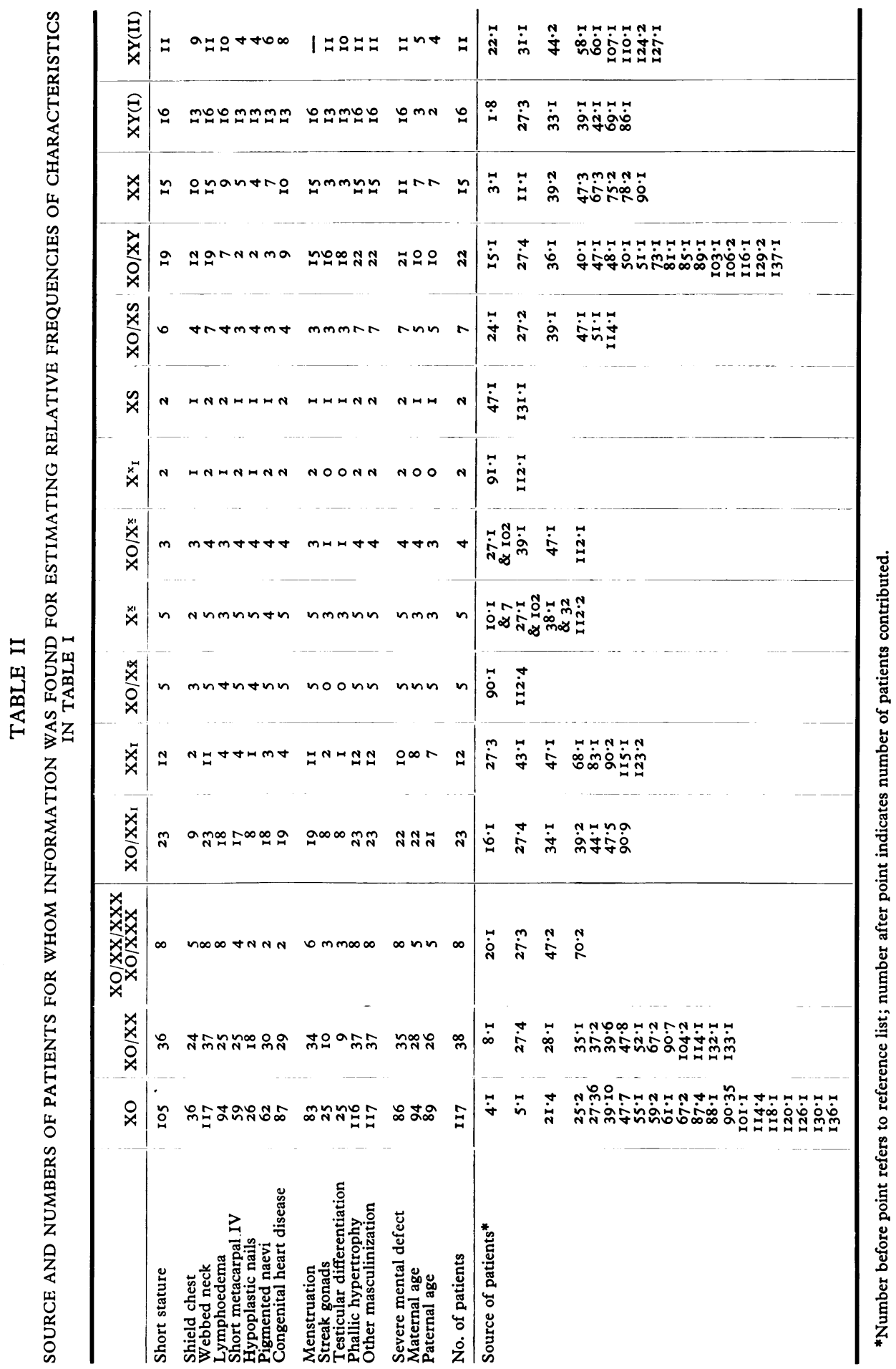


defect, and the mean parental ages at the birth of the patient, with standard deviations. For convenience of comparison, the number of patients affected with each characteristic is expressed as a percentage, though the number of patients is very small in several of the karyotype categories. The absolute number of cases in each class is given in Table II.

The XO Group. Short stature appears to be the only clinical finding invariably associated with an XO karyotype in adult women with gonadal dysgenesis; in at least 40 of the II 7 patients, it played no part in the selection of cases. The majority of XO patients have at least several of the Turner stigmata, and there is little evidence that mental defect qualifies as one of these. Spontaneous menstruation is recorded in only 7 patients out of 83 , but it is not known whether these menstrual cycles are ovulatory or anovulatory, because ova were found in only 2 of the 24 cases in whom the gonads were examined. (Unfortunately the 24 cases included none of the 7 who menstruated.) However, it is clear that some patients enter puberty with a few primordial follicles as one convincing case had sufficient ovarian functions to give birth to a normal child (Bahner, Schwarz, Hienz, and Walter, 1960).

Apart from the atypical group mentioned in the next paragraph, masculinization of the external genitalia was found in only 3 otherwise classical cases, and this was confined to slight hypertrophy of the clitoris (Case 8 of de la Chapelle, 1962; Case 5 of Ferguson-Smith et al., 1964a; Case 2 of Froland, Lykke, and Zachau-Christiansen, 1963). In Frøland et al.'s patient, the mother had been treated for threatened abortion during pregnancy with 'proluton' (a progesterone preparation).

Three patients differ very much from the rest of the XO group (Bloise, de Assis, Bottura, and Ferrari, 1960; Bottura and Ferrari, 1962; Atkins and Engel, 1962). Two are of short stature, but only one of these had minor Turner stigmata; all three have masculinization of the external genitalia and were found to possess a gonadal streak on one side and a rudimentary testis on the other. In one case, the rudimentary testis was found in the left labium and was associated with unilateral regression of the Müllerian ducts. These cases are so similar to patients in the mosaic $\mathrm{XO} / \mathrm{XY}$ and $\mathrm{XO} / \mathrm{XS}$ groups that it is likely that they are examples of undetected mosaicism of one of these groups, or of unrecognized translocation of $\mathrm{Y}$ chromosome material to another chromosome. In view of this doubt about their classification, these three have been excluded from the Tables.
The XO/XX Group. The data clearly show that the cardinal features of Turner's syndrome are less frequent in the XO/XX group than in the XO group:? Seven out of 36 of the patients have stature in the normal range; spontaneous menstruation is more? common (7 out of 34), and the Turner stigmata are reduced, especially webbing of the neck and lym $-\frac{\bar{c}}{\bar{c}}$ phoedema at birth. Presumably, the expression of the Turner phenotype is modified by the presence of a normal XX cell line. A similar dilution effectes in cases of chromosome mosaicism is seen in those $-\overrightarrow{0}$ patients with chromatin-positive Klinefelter's syndrome who have a proportion of normal XY cellsw (e.g. Barr, Carr, Morishima, and Grumbach, 1962), and in patients with mongolism who show mosaicism for normal and trisomic cell lines (Clarke, î Edwards, and Smallpiece, I96I).

Streak gonads were found in the nine $\mathrm{XO} / \mathrm{XX}_{\vec{f}}$ cases submitted to exploratory laparotomy, but ${ }_{0}^{N}$ normal ovaries were found in an $\mathrm{XO} / \mathrm{XX}$ child examined post mortem (Mikkelsen, Frøland, and ${ }_{c}^{-}$ Ellebjerg, 1963), and it may be that $\mathrm{XO} / \mathrm{XX}$ individuals have a greater chance of fertility than XO individuals. Two cases were noted to be masculin- $\vec{\bullet}$ ized; in one, who also has mongolism, this wasor confined to clitoral hypertrophy (van Wijck, Blankenborg, and Stolte, 1964), and in the other there was? marked clitoral hypertrophy and virilism, both attributed to a hilus cell adenoma (Warren, Erkman, Cheatum, and Holman, 1964).

The $\mathrm{XO} / \mathrm{XX} / \mathrm{XXX}$ and $\mathrm{XO} / \mathbf{X X X}$ Groups. $\overrightarrow{\overrightarrow{0}}$ The five $\mathrm{XO} / \mathrm{XX} / \mathrm{XXX}$ cases and the three $\mathrm{XO} / 3$ $\mathrm{XXX}$ cases demonstrate the same type of modified Turner phenotype noted in the $\mathrm{XO} / \mathrm{XX}$ group. The XXX cell line appears to exert only a normalizing influence. This might be expected, because non- 0 mosaic XXX individuals do not appear to be distinguishable clinically from normal XX females (Johnston, Ferguson-Smith, Handmaker, Jones, and Jones 196I), though most reported XXX cases have been ascertained by sex chromatin surveys in? mental institutions. Only one of the eight cases? included in Table $I$ is reported to have low intelligence, but this need not be due to the abnormaln karyotype, as the patient had tuberculous meningitis in infancy (Hayward and Cameron, 1961).

The Ring-X Mosaic Chromosome Group.? Three patients have a large ring-X chromosomé with mosaicism of $\mathrm{XO} / \mathrm{XX}_{\mathrm{R}} / \mathrm{XX}_{\mathrm{R}} \mathrm{X}_{\mathrm{R}}, \mathrm{XO} / \mathrm{XX} / \mathbb{\mathbb { C }}_{\mathrm{D}}$ $\mathrm{XX}_{\mathrm{R}}$, and $\mathrm{XO} / \mathrm{XX}_{\mathrm{R}}$ types respectively (Lindsten ${ }^{+}$ and Tillinger, 1962; Lüers, Struck, and Nevinny- -0 Stickel, 1963; Hustinx and Stoelinga, 1964). All three are short in stature, have Turner stigmata, $\frac{?}{?}$ 
and two have menstruated spontaneously; none show masculinization. The clinical findings correspond most nearly to those observed in the XO XX group.

The $\mathbf{X X}_{\mathrm{I}}$ and $\mathrm{XO} / \mathrm{XX}_{\mathrm{I}}$ Groups. Clinical descriptions are meagre in several of the 12 patients reported to have an $\mathrm{XX}_{\mathrm{I}}$ (isochromosome $\mathrm{X}$ ) karyotype. None the less, they all appear to be typical cases of Turner's syndrome. It is of interest that three have Hashimoto's thyroiditis. The $\mathrm{XX}_{\mathrm{I}}$ and $\mathrm{XO} \mathrm{XX}_{\mathrm{I}}$ cases may be considered together for comparison with the $\mathrm{XO}$ and $\mathrm{XO} / \mathrm{XX}$ groups to assess the phenotypic effects of the isochromosome $X$. Relatively low frequencies of webbing of the neck, lymphoedema at birth, and congenital heart disease are the only striking differences from the $X O$ phenotype. In these three Turner stigmata, modification of the Turner phenotype is of the same order as in the $\mathrm{XO} / \mathrm{XX}$ group. The isochromosome patients differ from the XO XX group in that they are all short in stature and all fulfil the criteria (page I42) for Turner's syndrome. They also differ from both the $\mathrm{XO}$ and the $\mathrm{XO} / \mathrm{XX}$ groups in that the frequencies of multiple pigmented naevi and of hypoplastic nails appear to be higher. Streak gonads were observed in all cases submitted to laparotomy and only one $\mathrm{XO} \mathrm{XX}_{\mathrm{I}}$ case was masculinized (Case 22 of Ferguson-Smith et al., 1964a; Case 2 of Bergada, Cleveland, Jones, and Wilkins, 1962a). This patient had clitoral hypertrophy, associated with hyperplasia of the hilus cells in the medullary portion of the streak gonads.

The $\mathbf{X} \bar{x}$ and $X O / X \bar{x}$ Groups. Six patients have been reported to have an abnormal $\mathrm{X}$ chromosome similar in size to chromosomes $13-15$, and interpreted as a deletion involving most of the short arm. In one the karyotype is $\mathrm{X} \overline{\mathbf{x}}$ without apparent mosaicism (Jacobs et al., 196I), the others are $\mathrm{XO} / \mathrm{X} \overline{\mathrm{x}}$ mosaics (Lindsten, 1963; P. E. Polani, 1964, personal communication). With the possible exception of one 32-year-old patient who is $60.5 \mathrm{in}$. ( $154 \mathrm{~cm}$.) in height, all fulfil the criteria for Turner's syndrome.

The $X \times$ and $X O / X \times$ Groups. Ten patients are known in whom there is a structural abnormality of an $\mathrm{X}$ chromosome interpreted as a deletion involving most of the long arm. Four have $\mathrm{XO} / \mathrm{X} \times$ mosaicism, five have $X^{x}$ without detected mosaicism, and one has $\mathrm{XX} / \mathrm{X} \underline{\mathrm{x}}$ mosaicism (Case 2 of de Grouchy, Lamy, Yaneva, Salomon, and Netter, I96Ib). Only two of these patients have Turner's syndrome, and, as both are $\mathrm{XO} / \mathrm{X}^{\mathrm{x}}$ mosaics, the Turner phenotype can be attributed to the effect of the XO cell line.
The $\mathrm{XX} / \mathrm{X} \mathrm{x}$ patient is of normal stature and appearance; she presented for investigation with the SteinLeventhal syndrome. Four of the seven remaining patients had laparotomy and were found to have streak gonads without masculinization. Although one might expect undetected $\mathrm{XO} / \mathrm{X} \times$ mosaicism in at least several of the $\mathrm{X}^{\mathrm{x}}$ patients, it is surprising that only two are short in stature (P. E. Polani, I964, personal communication) and only two show a Turner stigma; in each instance, this is the presence of multiple pigmented naevi. These findings suggest that deletion of the long arm of the $\mathrm{X}$ chromosome can cause streak gonads but is not sufficient by itself to cause the extreme short stature and the multiple stigmata of Turner's syndrome, and that these features are only found when the deletion includes the short arm.

The $\mathbf{X}^{x_{1}}$ Group. Only two patients are known to have a small metacentric $\mathrm{X}$ chromosome interpretable as an isochromosome for the short arm of the $\mathrm{X}$ chromosome or as a deletion of part of the long arm (J. Lindsten, 1964, personal communication; P. E. Polani, I964, personal communication). Both have primary amenorrhoea and are $6 \mathrm{I}$ and $6 \mathrm{I} \cdot 5 \mathrm{in}$. in height respectively. One has short IVth metacarpals and the other has multiple pigmented naevi, but these are the only Turner stigmata. They are thus phenotypically similar to patients in the $X^{\mathbb{X}}$ group.

The XS and XO XS Groups. Minute abnormal chromosomes, smaller than chromosome 22, have been reported in association with gonadal dysgenesis in at least I I patients. The clinical, chromosomal, and sex chromatin findings make it almost certain that they are abnormal sex chromosomes, but it is not yet possible to establish cytologically whether they are $\mathrm{X}$ or $\mathrm{Y}$ chromosome aberrations. Their morphology varies from case to case; in some the abnormal chromosome is metacentric, in others it appears acrocentric, and in at least one case it is a small ring chromosome. In 2 patients the karyotype is $\mathrm{XS}$ without mosaicism, in 6 there is $\mathrm{XO} / \mathrm{XS}$ mosaicism, I patient has $\mathrm{XO} / \mathrm{XS} / \mathrm{XXS}$ mosaicism, and another patient has XX/XS mosaicism. All patients are short in stature and Turner stigmata are specifically described in 8 and stated to be absent in none. The two XS patients show clitoral hypertrophy and posterior fusion of the labioscrotal folds; in the XS patient submitted to laparotomy, rudimentary testes were found at the ovarian sites. Two of the $6 \mathrm{XO}$ XS patients also showed clitoral hypertrophy, and in one of these a rudimentary testis was found on one side of the abdomen 
and a gonadal streak on the other; the two other $\mathrm{XO} / \mathrm{XS}$ cases submitted to laparotomy had bilateral gonadal streaks. Of the two patients not included in the Table on account of the special nature of the mosaicism, the XO/XS/XXXS patient of Fraccaro, Bott, Salzano, Russell, and Cranston (1962) had Turner's syndrome with clitoral hypertrophy, and the XX/XS patient of Becker, Hayles, and Albert (1963b) had short stature and shield chest, but no other major Turner stigmata and no masculinization.

The major implications of the findings in this group are that the $S$ chromosome is a very deleted sex chromosome which sometimes carries male determinants and (in these cases at least) is thus probably a deficient $\mathrm{Y}$ chromosome. As all cases in this group are short in stature, and most show Turner stigmata, it follows that a structurally abnormal $\mathrm{Y}$ may have similar phenotypic effects to a structurally abnormal $\mathrm{X}$; this situation is understandable on the hypothesis that there are loci on the $\mathrm{Y}$ chromosome that are homologous with loci on the $\mathrm{X}$.

The XO/XY Group. The 22 patients with this karyotype show a very variable phenotype: 16 were reared as females and 6 as males. Though all have abnormal gonadal development, there is no clearcut type, and the gonads vary from typical streak gonads to sterile scrotal testes. Sex differentiation is asymmetrical in 7 patients, a streak gonad developing on one side and a rudimentary testis on the other; 16 show masculinization of the external genitalia. Turner stigmata and short stature may or may not be present, the absence of the latter appearing to be the only feature distinguishing this group from the $\mathrm{XO} / \mathrm{XS}$ group described above.

Unusual Karyotypes in Gonadal Dysgenesis. Several unusual karyotypes have been described which cannot be classified in any one of the above groups and are not included in the Tables. Most of these are represented by single cases, they all have $\mathrm{Y}$ chromosomes, or $\mathrm{Y}$ chromosome aberrations, in at least a proportion of cells, and their phenotypes are as variable as in the $\mathrm{XO} / \mathrm{XY}$ group.

(i) $X O / X Y Y$ mosaicism was found in one patient with the complete Turner's syndrome, without masculinization (Jacobs et al., 1961), and in another patient of normal height, with two undifferentiated gonads and no uterus (Cooper, Kupperman, Rendon, and Hirschhorn, 1962).

(ii) $X O / X X / X Y$ mosaicism is reported in a male pseudohermaphrodite of normal height without Turner stigmata (Schuster and Motulsky, 1962).
The patient had a left gonadal streak and a right rudimentary testis.

(iii) $X O / X \times Y$ mosaicism was found in a male $\stackrel{\mathbb{P}}{\rightarrow}$ pseudohermaphrodite with uterus, Fallopian tubes, $\overrightarrow{\vec{F}}$ and bilateral rudimentary testes in place of ovaries (Miles, Luzzatti, Storey, and Peterson, 1962).

(iv) $X X_{\mathrm{I}} / X X_{\mathrm{I}}^{6} Y^{\prime}$ mosaicism was found in a chromatin-positive, I I-year-old boy with short stature, $\vec{\nabla}$ Turner stigmata, and undescended testes (Oikawa and Blizzard, I96I; Solomon, Hamm, and Green, 1964). The boy and his normal father had an $\vec{\circ}$ abnormal metacentric ' $Y$ ' chromosome, possibly the result of a pericentric inversion.

(v) A Y chromosome aberration, interpreted as an isochromosome for the long arm, is reported in two patients; one is $X Y_{I}$ (Court-Brown, Harnden, i Jacobs, Maclean, and Mantle, I964), the other is an ? $X O / X Y_{\mathrm{I}} / X Y_{\mathrm{I}} S$ mosaic (Klevit, Mellman, and Eber- $\overrightarrow{\vec{N}}$ lein, 1963). Both are of short stature. The XY I case $\mathrm{N}$ has Turner stigmata, streak gonads, and no mas- $\frac{}{3}$ culinization. The $X O / X Y_{\mathrm{I}} / X Y_{\mathrm{I}} S$ mosaic has appa- $\vec{c}$ ently no Turner stigmata but has ambiguous external genitalia, a right gonadal streak, and left rudimentary testis.

(vi) $X X / X Y$ mosaicism is described in three of strikingly different patients. One is a woman with streak gonads (Forteza, Bonilla, Báguena, Monmeneu, Galbis, and Zaragozá, 1963), another is a true hermaphrodite (Waxman, Gartler, and Kelley, 1962), and the third is a healthy man (Zuelzer, Beattie, and Reisman, 1964).

The XX Group. I5 patients were found with an apparently normal $\mathrm{XX}$ karyotype associated with evidence of gonadal dysgenesis with or without short stature and Turner stigmata. These are listed together in the Tables, though the possibility of sex chromosome mosaicism, or undetected $\mathrm{X}$ chromosome deletion, cannot be entirely ruled out. The group does not include the large number of XX true hermaphrodites, the rare $\mathrm{XX}$ Klinefelter patient (de la Chappelle, Hortling, Niemi, and Wennström, 1964; M. A. Ferguson-Smith, un- $\frac{7}{0}$ published observations), nor the $\mathrm{XX}$ patient of Shah, Naik, Mahajan, Dave, and Paymaster (I96I) N who shares features of male pseudohermaphroditism $N$ and Klinefelter's syndrome.

The XY Group. Patients with gonadal dysgenesis and an apparently normal XY karyotype $\stackrel{\circ}{\subset}$ are of two classes. The first class (Group I in $\$$ Table I) consists of patients without Turner? stigmata and usually of normal height, who show a $\frac{T}{0}$ wide variation in sex differentiation, apparently $\underset{\vec{D}}{\circ}$ depending on the degree of testicular development 
of the gonads. This group includes patients of female phenotype with streak gonads ('pure gonadal dysgenesis'), and male pseudohermaphrodites with unilateral streak gonads or bilateral rudimentary testes. The second class (Group II) are phenotypic males with short stature and Turner stigmata (the 'male Turner syndrome'), several of whom have germinal aplasia of the testes.

Parental Age. Although the number of informative cases is very small in several of the karyotype categories, the mean parental ages listed in Table I show no trend which might suggest that increased maternal age is important in the aetiology of any of the chromosome aberrations described. This is in contrast to the findings in Klinefelter's syndrome (Ferguson-Smith, Mack, Ellis, Dickson, Sanger, and Race, 1964b) where increased maternal age is prominent in a high proportion of cases. There may possibly be an increase in paternal age in the $\mathrm{XO} \mathrm{XX}_{\mathrm{I}}$ group which, if confirmed, would be consistent with the evidence from $\mathrm{Xg}$ grouping in seven families that the isochromosome $X$ is of paternal origin (Lindsten, Fraccaro, Polani, Hamerton, Sanger, and Race, 1963; Ferguson-Smith et al., I964a). The findings in the XO group confirm the lack of parental age effect previously reported in 63 chromatin-negative patients with Turner's syndrone (Boyer, Ferguson-Smith, and Grumbach, I96I).

\section{Discussion}

Several implications of these karyotype-phenotype correlations are now considered-(a) monosomy of X-and Y-homologous loci is the usual cause of Turner's syndrome; (b) $\mathrm{Y}$ chromosome deficiency is a cause of abnormal male differentiation and intersexuality; (c) embryonic germ cell degeneration may play an important part in the pathogenesis of gonadal dysgenesis; and (d) part of the short arm of the inactivated $\mathrm{X}$ chromosome in female somatic cells remains genetically active.
The Cause of Turner's Syndrome. In patients who have a demonstrable chromosome aberration, the karyotype-phenotype correlations show that the aberration common to all those with the complete Turner's syndrome is deficiency (or monosomy) of the short arm of one $\mathrm{X}$ chromosome. Thus non-mosaic $\mathrm{XO}, \mathrm{XX}_{\mathrm{I}}$, or $\mathrm{X} \overline{\mathrm{X}}$ cases have Turner's syndrome, while $\mathrm{X}^{\mathrm{x}}$ and $\mathrm{X}^{\mathrm{x}} \mathrm{I}$ cases do not. In patients showing mosaicism of cells with $\mathrm{XO}$, $\mathrm{XX}_{\mathrm{I}}$, or $\mathrm{X} \overline{\mathrm{x}}$ karyotypes and cells with normal karyotypes, there are variable phenotypes intermediate between Turner's syndrome and normal. In fact, most of the variants of Turner's syndrome can be explained on the assumption that there is a range of phenotypic expression from normal female to Turner's syndrome and from normal male to Turner's syndrome, depending on the degree of sex chromosome deficiency intermediate between $\mathrm{XX}$ and $\mathrm{XO}$, and between $\mathrm{XY}$ and XO, respectively. This sex chromosome deficiency is of two main types (Fig. I): sex chromosome mosaicism and sex chromosome deletion. In mosaic cases, it is conceivable that the phenotype depends on the proportion of $\mathrm{XO}$ to normal cells in the various tissues during differentiation. In the structural $\mathrm{X}$ aberration group, the phenotype clearly depends on the extent and localization of the deletion, for the complete Turner's syndrome occurs only when the short arm of the $\mathrm{X}$ is deficient. The partial masculinization seen in XS cases cannot easily be explained except by assuming that the $S$ chromosome is a deficient $\mathrm{Y}$. The Turner stigmata in these $\mathrm{XS}$ cases must then be the result of deletion, not of an $X$, but of a Y. It seems to follow inevitably that the $\mathrm{X}$ and $\mathrm{Y}$ chromosomes have homologous loci, and that monosomy for certain of these loci result in short stature and Turner stigmata. In addition, the postulated homologous loci must be in the short arm of the $\mathrm{X}$, as non-mosaic patients with long arm deletions of the $\mathrm{X}$ chromosome do not have Turner's syndrome. Support for the existence of homologous loci comes exclusively from the cytological observations of pairing between the short arm of the $\mathrm{X}$ and

NORMAL FEMALE $\longrightarrow$ TURNER'S SYNDROME $\longleftarrow$ NORMAL MALE

A

B

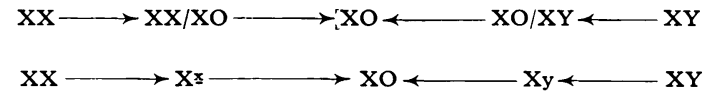

FIG. I. Diagram illustrating the concept of variable sex chromosome deficiency in Turner's syndrome and its variants $(y=a$ deleted $\mathrm{Y}$ chromosome).

A. Variable deficiency due to sex chromosome mosaicism.

B. Variable deficiency due to sex chromosome deletion. 
one of the arms of the $\mathrm{Y}$ chromosome during meiosis (Koller, 1937; Sachs, 1954; Ford and Hamerton, 1956; M. A. Ferguson-Smith, unpublished observations), for there is as yet no conclusive genetic evidence of partial sex linkage in man (see Stern, 1960). However, the precocious condensation of the $\mathrm{XY}$ sex bivalent during meiotic prophase (reminiscent of $\mathrm{X}$ inactivation in female somatic cells) may reduce crossing-over between pairing segments.

The principal conclusions from the karyotypephenotype correlations in patients with demonstrable structural sex chromosome aberrations may be stated briefly as follows.

(I) Large deletions of any part of the $\mathrm{X}$ chromosome are usually associated with streak gonads.

(2) Monosomy of parts of the short arm of the X (including certain of the presumptive Y-homologous loci) results in short stature and Turner stigmata, whereas monosomy of the long arm does not.

(3) Deletion of part of the Y chromosome may lead to short stature and Turner stigmata (if certain $\mathrm{X}$-homologous loci are included) and a variable failure of testicular development of the gonads, the latter presumably depending on whether or not male determinants are included in the deletion. (The findings in the $X Y_{I}$ case (p. I48) seem to suggest that the postulated homologous loci are on the short arm of the $\mathrm{Y}$ chromosome. Many more similar cases, in which mosaicism has been excluded, are required to prove this.)

(4) The expression of the Turner phenotype is slightly less marked in $\mathrm{XX}_{\mathrm{I}}$ and $\mathrm{XO} / \mathrm{XX}_{\mathrm{I}}$ cases when compared with $\mathrm{XO}$ cases. In some cases, this may be because some of the Y-homologous loci nearest to the centromere are not included in the deficiency accompanying the formation of the presumed isochromosome.

It is theoretically possible that undetected mosaicism, or small deletions involving the postulated X- and Y-homologous loci at present beyond the resolution of the microscope, may be shown in future to be the cause of short stature and Turner stigmata in patients with apparently normal XX and $\mathrm{XY}$ karyotypes; such a mechanism would explain the so-called 'male Turner syndrome' (Group XY [II] see Table I). To explain satisfactorily the occurrence of two affected XX sibs with streak gonads and short stature, where the parents are normal and consanguineous (Josso, de Grouchy, Frézal, and Lamy, I963), homozygosis for a small deletion or mutation involving the Y-homologous loci might be postulated; an alternative possibility is homozygosis for an autosomal mimicking mutant. Homozygosis for a large $\Omega$ deficiency of the $\mathrm{X}$ chromosome is probably lethal $\stackrel{\mathbb{D}}{\stackrel{\Phi}{~}}$ because OY, $X_{I} Y$, and $\times Y$ sex complements are $\stackrel{T}{?}$ unknown, and because in $\mathrm{X} \times$ and $\mathrm{XX}_{\mathrm{I}}$ individuals $\vec{\Rightarrow}$ the abnormal $X$ is always the inactivated $X$ (p. 152$)$. ल)

As monosomy of the $\mathrm{X}$ - and $\mathrm{Y}$-homologous loci $\mathrm{C}$ seems to be the important defect in the Turner $\frac{\overline{\bar{D}}}{\bar{D}}$ group of patients, it is conceivable that trisomy for $\frac{\Phi}{\widetilde{D}}$ these loci might produce phenotypic effects that are $\varnothing$ shared by XXX, XXY, and XYY individuals. This § expectation appears to be confirmed at least by the $\vec{\theta}$ demonstration of a high incidence of mental retard- ation in all three sex chromosome aberrations. $\vec{\omega}$ Table I shows that, in the Turner group, the incidence of mental retardation is comparatively low.

An alternative theory has been proposed to in explain the Turner phenotype in $\mathrm{XO}$ and $\mathrm{XX}_{\mathrm{I}} \mathrm{N}$ patients (Gartler and Sparkes, 1963). This is based $\vec{A}$ on the evidence that the isochromosome $\mathbf{X}$ is always $N$ the inactivated $X$, and on the hypothesis that $\mathrm{O}$ inactivation of one or other of the $\mathrm{X}$ chromosomes is determined at random in different cells (p. I52). Thus, $\mathrm{XO}$ cells with the $\mathrm{X}$ inactivated, and $\mathrm{XX}_{\mathrm{I}}$ cells with the normal $X$ inactivated, would be $\vec{\varphi}$ effectively homozygous deficient for a large part of of the $\mathrm{X}$, a situation incompatible with survival. If sufficient cells were lost embryonic death might result. Smaller amounts of cell loss might lead to short stature and malformation. However, the theory has several drawbacks; for example, it $\frac{\mathscr{Q}}{\mathbb{Q}}$ does not explain why the syndrome occurs in XX $\cong$ and $\mathrm{XY}$ individuals, nor why the brain, for instance, $\overrightarrow{\vec{O}}$ should remain normal in XO individuals while the 3 musculo-skeletal system is invariably abnormal. The theory also appears to be contradicted by the findings in the $\mathrm{Xx}^{\mathrm{x}}$ individuals. According to the theory, one would expect that random inactivation 0 in an $X^{x}$ individual would lead either to short $\frac{O}{3}$ stature due to loss of cells with the normal $\mathrm{X}$ inactivated or, if these cells were viable, to the develop- $\frac{\text { O }}{3}$ ment of a normal phenotypic female whose somatic cells showed mosaicism for normal-sized and small 은 sex chromatin bodies. The finding of only small sex $\rightarrow$ chromatin bodies and normal stature seems to be convincing evidence against this theory. None the N less, the theory provides an attractive explanation for the apparently preferential inactivation of ${ }^{N}$ markedly deficient $\mathrm{X}$ chromosomes.

Role of the Y Chromosome in Male Differentiation. It is now widely accepted that in man the principal factors controlling sex determination are $\stackrel{?}{+}$ male determinants carried by the $\mathrm{Y}$ chromosome. $T$ Thus, testes are found in individuals with $X Y$, 웅 $\mathrm{XXY}, \mathrm{XXXY}$, and XXXXY karyotypes, but not in 
individuals with only $\mathrm{XO}, \mathrm{XX}, \mathrm{XXX}$ or $\mathrm{XXXX}$ karyotypes. The evidence from the karyotypephenotype correlations shows that in this series of patients a degree of testicular development (i.e. gonads intermediate between complete testes and 'streaks') exists only in persons who have a $\mathrm{Y}$ chromosome, or $\mathrm{Y}$ chromosome aberration, in at least a proportion of cells. This suggests that a quantitative deficiency of the $\mathrm{Y}$ chromosome may lead to incomplete male determination, and thus be a cause of defective testicular development.

The embryonic castration experiments of Jost (1947, 1958) and others show that in mammals male differentiation of the genital ducts and masculinization of the external genitalia depends on the suppression of the Müllerian ducts, and stimulation of the Wolffian ducts and external genitalia, by the embryonic testes. Destruction of the undifferentiated embryonic gonad before a critical stage of gonadogenesis produces female sex differentiation irrespective of genetic sex. Unilateral gonadal destruction in a male embryo produces female differentiation of the genital ducts on the same side. Variation in the timing and extent of testicular destruction produces types of sex differentiation intermediate between male and female.

Gonadal dysgenesis in man may be considered to be a natural counterpart of the embryonic castration experiments. The gonadal abnormality may be caused in an embryo either by extrinsic damage (independently of karyotype), or by germ cell degeneration due to an abnormal $\mathrm{X}$ chromosome complement (see below), or by a deficiency of the $\mathrm{Y}$ chromosome. Whatever the cause, the effect in terms of differentiation of the genital ducts is the same as embryonic castration. In this context, the streak gonad is analogous to the gonad destroyed by early castration. It is incapable of inducing masculinization even though a $\mathrm{Y}$ chromosome is present, and is therefore always found in association with a uterus and Fallopian tube. Gonadal dysgenesis in patients without a $\mathrm{Y}$ chromosome is, of course, always associated with female genital ducts. But in individuals with a $\mathrm{Y}$ chromosome (or part of a $\mathrm{Y}$ chromosome) in a proportion of cells, there may be testicular development to an extent that may or may not be capable of inducing male differentiation of the genital ducts and masculinization of the external genitalia, and that thus may or may not be associated with uterus and Fallopian tubes.

The only apparent exceptions to this concept of human sex differentiation are the true hermaphrodites and Klinefelter patients with an XX karyotype and the $\mathrm{XX}$ male pseudohermaphrodite described by Shah et al. (196I). Masculinization of the external genitalia may also occur in patients with gonadal dysgenesis who have no $\mathrm{Y}$ chromosome, as a result of a virilizing gonadal tumour (e.g. Warren et al., 1964).

Role of Germ Cells in the Pathogenesis of Gonadal Dysgenesis. There is considerable evidence that the successful migration of germ cells from the primitive gut and their presence in the genital ridge is necessary for normal ovarian development (see Dantchakoff, 1950; Jost, 1958; Jones, Ferguson-Smith, and Heller, 1963). Recently, this important role of germ cells in gonadal development has been greatly strengthened by the experiments of Hemsworth and Jackson (1963a, b). They demonstrated that if busulphan is administered to pregnant rats on or about the 1 $3^{\text {th }}$ day after insemination, i.e. at the time of migration and proliferation of the embryo's germ cells, these are destroyed, so that female offspring are born with sterile atrophic ovaries and males with sterile testes. The striking similarity of these ovaries to streak gonads, and of the testes to the prepubertal testes with germinal aplasia in XXY humans (FergusonSmith, 1959) and in XXY mice (M. F. Lyon, 1963b, personal communication), suggests that at least some types of abnormal sex chromosome complements lead to germ cell degeneration.

This state of affairs is interpretable on the X-inactivation theory (Lyon, 196I, 1962, 1963a; Beutler, Yeh, and Fairbanks, 1962), which asserts that during early embryogenesis one or other of the two $\mathrm{X}$ chromosomes in female somatic cells becomes genetically inactivated at random. Of particular relevance here is the finding in mammals that oogonia, in contrast to somatic cells, at no time show sex chromatin (Ohno, Kaplan, and Kinosita, 1960); this suggests strongly that both $\mathrm{X}$ chromosomes are genetically active in oogonia, and that oogonia require two active $\mathrm{X}$ chromosomes for their normal development. In fact, this absence of $\mathrm{X}$ inactivation in female germ cells may reflect the important difference between germ cells and somatic cells, though at present there is no such direct evidence of a comparable difference in normal males. If embryonic germ cells do not normally undergo $\mathrm{X}$ inactivation, it is probable that they are more susceptible than somatic cells to genetic imbalance produced by abnormal sex chromosome complements. This would be a satisfactory explanation of the usual absence of germ cells in most patients with streak gonads, and in the testes of male patients with sex chromosome aberrations (e.g. Klinefelter's syndrome). 
The occasional survival of a limited number of germ cells in XXY and XO persons, and the observations of fertility in non-mosaic XXX and $X Y Y$ persons, require further explanation. As all known offspring of XXX and XYY patients have normal sex chromosome complements, it is possible that non-disjunctional events involving the sex chromosomes during proliferation of the germ cells have led to the selection and survival of a small proportion of germ cells with normal sex chromosome complements. Precedence for this type of mechanism has been demonstrated recently by a study of oogenesis in the creeping vole, Microtus oregani (Ohno, Jainchill, and Stenius, 1963). The sex chromosome constitution of the normal female in this species is $\mathrm{XO}$, but $\mathrm{XX}$ oogonia are produced by a process of selective non-disjunction.

Other varieties of gonadal dysgenesis are probably adequately explained by factors such as $\mathrm{Y}$ chromosome deficiency, or deleterious agents acting through the mother to cause defective testicular development; it is significant that germ cells may or may not be absent in these cases (see Bergada et al., I962a; Bergada, Cleveland, Jones, and Wilkins, I962b).

Structural $\mathbf{X}$ Aberrations and the $\mathbf{X}$-inactivation Theory. In patients with structural $\mathrm{X}$ chromosome aberrations it now appears that the abnormal $\mathbf{X}$ chromosome is always the inactivated one. For the abnormal $\mathrm{X}$ is consistently the sex chromatin-forming X (Maclean, 1962; FergusonSmith, 1962), and DNA labelling studies show that it is also always the late-replicating $X$ (Muldal, Gilbert, Lajtha, Lindsten, Rowley, and Fraccaro, 1963; Giannelli, 1963). Therefore, according to the Lyon principle, one might not expect there to be phenotypic differences between $\mathrm{XO}, \mathrm{XX}_{\mathrm{I}}, \mathrm{X} \mathrm{x}$, or $\mathrm{X} \overline{\mathrm{X}}$ individuals. The fact that there are important phenotypic differences requires explanation, and it seems that there are several alternative possibilities. These are that both $\mathrm{X}$ chromosomes are genetically active in the early embryo, or that inactivation does not involve the entire $\mathrm{X}$ chromosome, or that both these factors operate.

The first of these explanations is based on the observation that sex chromatin does not appear in the early embryo until the 16-18th day (Park, 1957); presumably both $\mathrm{X}$ chromosomes are active until then, and it is conceivable that an $\mathrm{X}$ chromosome abnormality acting before then might disturb normal embryogenesis and lead to permanent effects on the adult phenotype. However, both cytological and genetic evidence seem to favour the explanation that part of the inactivated $X$ always remains genetically active. In addition, they suggest that the active part is in the short arm. The cytological evidence comes from estimations of the relative size of the sex chromatin body in $\mathrm{XX}_{\mathrm{I}}, \mathrm{X} \overline{\mathrm{x}}, \mathrm{X} \mathrm{x}$, and $\mathrm{XX}$ individuals, which indicate that part of the short arm of the sex-chromatin-forming $X$ is euchromatic (Maclean, 1962). The genetic evidence is derived from studies which attempt to demonstrate a mosaic pattern of activity in the somatic cells of women heterozygous for X-linked alleles (on the principle that inactivation affects one or other of the $\mathrm{X}$ chromosomes at random). The $\mathrm{X}$-linked locus for glucose-6-phosphate dehydrogenase (G6PD) has been shown conclusively to demonstrate this mosaic pattern of activity (Davidson, Nitowsky, and Childs, 1963), but the locus for the $X g^{\text {a }}$ blood group has been shown not to demonstrate mosaicism (Gorman, Dire, Treacy, and Cahan, 1963), implying that of the two only the locus for G6PD is inactivated. $\mathrm{Xg}$ grouping in families of $\mathrm{XX}_{\mathrm{I}}$ cases (Lindsten et al., 1963; Ferguson-Smith et al., 1964a), when taken in conjunction with the results of Gorman et al. (1963), provide strong evidence that the $\mathrm{Xg}$ locus is on the short arm of the $\mathrm{X}$ chromosome, and thus that part of the short arm escapes inactivation.

The karyotype-phenotype correlations show that in patients with streak gonads, there is very little difference in phenotype between $\mathrm{XX}$ and $\mathrm{X}^{\mathrm{x}}$ individuals, or between $\mathrm{XO}, \mathrm{X} \overline{\mathrm{X}}$, and $\mathrm{XX}_{\mathrm{I}}$ individuals. Thus the presence of the short arm of the inactivated $\mathrm{X}$ chromosome is much more important in terms of the phenotype than the long arm. This again suggests that part of the short arm of the inactivated $\mathrm{X}$ escapes inactivation, whereas most of the long arm does not.

All these observations seem consistent with the hypothesis that there are loci in the short arm of the $\mathrm{X}$ chromosome, which escape $\mathrm{X}$-inactivation, which are homologous with loci in the $\mathrm{Y}$ chromosome, and which lead to Turner's syndrome when present in only single dose.

\section{Summary}

307 patients with gonadal dysgenesis and a variety of sex chromosome aberrations have been assembled from the literature in order to assess possible correlations between the chromosomal and clinical findings.

It is found that monosomy of the short arm of the $\mathrm{X}$ chromosome is the decisive factor in the causation of short stature and congenital malformations in Turner's syndrome. However, some patients with probable Y chromosome aberrations also show short 
stature and Turner stigmata, in addition to defective testicular development with ambiguous genitalia. Evidence is presented in support of a hypothesis that there is a range of phenotypic expression from normal female to Turner's syndrome, and from normal male to Turner's syndrome, depending on the degree of sex chromosome deficiency intermediate between XX and XO, and XY and XO complements respectively. The karyotype-phenotype correlations show that the sex chromosome deficiency is of two main types, sex chromosome mosaicism, and deletion of the $\mathrm{X}$ or $\mathrm{Y}$ sex chromosomes. A necessary requirement of the hypothesis is that the deficiency involves $\mathrm{X}$ - and $\mathrm{Y}$-homologous loci, and the evidence for the existence of these is presented. The findings suggest that part of the short arm of the inactivated $\mathrm{X}$ chromosome, including postulated Y-homologous loci, is genetically active in female somatic cells.

The karyotype-phenotype correlations are discussed in relation to theories of male differentiation of the genital ducts and external genitalia, and in relation to the role of embryonic germ cell degeneration in the pathogenesis of streak gonads and sterile testes.

I am indebted to Dr Mary F. Lyon, Dr Bernard Lennox, and Dr James $\mathrm{H}$. Renwick for helpful discussion during the preparation of the manuscript, and to Professor Paul E. Polani, Drs K. L. Becker, J. Farquhar, J. de Grouchy, J. Lindsten, and T. N. MacGregor for kind permission to include unpublished information about their patients. The study was supported by Research Grants 5804 and 784I from the U.S. Public Health Service.

\section{REFERENCES}

I. Alexander, D. S., and Ferguson-Smith, M. A. (196r). Chromosomal studies in some variants of male pseudohermaphroditism. Pediatrics, 28, 758 .

2. Atkins, L., and Engel, E. (1962). Absence of the $Y$ chromosome (XO sex-chromosome constitution) in a human intersex with an extra-abdominal testis. Lancet, $2,20$.

3. Aubert, L. (1962). Syndrome de Turner avec test de Barr positif et sex génétique féminin normal. Ann. Endocr. (Paris), 23, 225.

4. Aula, P., Hjelt, L., and Kauhtio, J. (I96I). Chromosomal investigation in congenital malformations. Ann. Paediat. Fenn., 7, 206.

5. Bahner, F., Schwarz, G., Hienz, H. A., and Walter, K. (I960). Turner-Syndrom mit voll ausgebildeten sekundären Geschlechtsmerkmalen und Fertilität. Acta endocr. (Kbh.), $35,397$.

6. Barr, M. L., Carr, D. H., Morishima, A., and Grumbach, M. M. (1962). An XY/XXXY sex chromosome mosaicism in a mentally defective male patient. f. ment. Defic. Res., 6, 65.

7. Becker, K. L. (1964). Personal communication.

8. - Burgert, E. O., and Albert, A. (1963a). Ovarian dysgenesis with sexual development and menstruation (XO/XX mosaicism). Proc. Mayo Clin., 38, 367.

9. $\longrightarrow$, Hayles, A. B., and Albert, A. (1963b). Gonadal dysgenesis due to mosaicism of an $X$ chromosome fragment. ibid., 38, 422 .
I0. - Paris, J., and Albert, A. (I963c). Ovarian dysgenesis due to deletion of the $\mathrm{X}$ chromosome. ibid., 38, 389 .

I I. - - , and - (I963d). Gonadal dysgenesis and hypopituitarism (deletion-induced hemizygosity). ibid., 38, 467.

12. Bergada, C., Cleveland, W. W., Jones, H. W., Jr., and Wilkins, L. (1962a). Gonadal histology in patients with male pseudohermaphroditism and atypical gonadal dysgenesis: relation to theories of sex differentiation. Acta endocr. (Kbh.), 40, 493.

13. - - - - - - and - (1962b). Variants of embryonic testicular dysgenesis: bilateral anorchia and the syndrome of rudimentary testes. ibid., 40, 521 .

14. Beutler, E., Yeh, M., and Fairbanks, V. F. (1962). The normal human female as a mosaic of $\mathrm{X}$-chromosome activity: studies using the gene for G-6-PD-deficiency as a marker. Proc. nat. Acad. Sci. (Wash.), 48, 9.

15. Blank, C. E., Bishop, A., and Caley, J. P. (1960). Example of $\mathrm{XY} / \mathrm{XO}$ mosaicism. Lancet, 2,1450 .

16. - Gordon, R. R., and Bishop, A. (I96I). Atypical Turner syndrome. ibid., $\mathbf{I}, 947$.

17. Bloise, W., De Assis, L. M., Bottura, C., and Ferrari, I. (1960). Gonadal dysgenesis (Turner's syndrome) with male phenotype and XO chromosomal constitution. ibid., 2, 1059.

18. Bottura, C., and Ferrari, I. (1962). Male pseudohermaphroditism with XO chromosomal constitution on bone-marrow cells. Brit. med. F., 2, I 100.

I9. Boyer, S. H., Ferguson-Smith, M. A., and Grumbach, M. M. (196I). The lack of influence of parental age and birth order in the aetiology of nuclear sex chromatin-negative Turner's syndrome. Ann. hum. Genet., 25, 215.

20. Carr, D. H., Morishima, A., Barr, M. L., Grumbach, M. M., Lüers, T., and Boschann, H. W. (1962). An XO/XX/XXX mosaicism in relationship to gonadal dysgenesis in females. f. clin. Endocr., 22, 671.

21. Christiaens, L., Laude, M., Fontaine, G., and Dehaene, P. (196I). Syndrome d'Ullrich-Turner Haplo X. Arch. franç. Pédiat., 18, ros3.

22. Chu, E. H. Y., Warkany, J., and Rosenstein, R. B. (I96I). Chromosome complement in a case of the "male Turner syndrome". Lancet, $x, 786$.

23. Clarke, C. M., Edwards, J. H., and Smallpiece, V. (I96r). $2 \mathrm{I}$-Trisomy/normal mosaicism in an intelligent child with some mongoloid characters. ibid., $1,1028$.

24. Conen, P. E., Bailey, J. D., Allemang, W. H., Thompson, D. W., and Ezrin, C. (I96I). A probable partial deletion of the $\mathrm{Y}$ chromosome in an intersex patient. ibid., 2, 294.

25. - and Glass, I. H. (1963). 45/XO Turner's syndrome in the newborn: report of two cases. F. clin. Endocr., 23, I.

26. Cooper, H. L., Kupperman, H. S., Rendon, O. R., and Hirschhorn, K. (1962). Sex-chromosome mosaicism of type XYY/XO. New Engl. F. Med., 266, 699.

27. Court Brown, W. M., Harnden, D. G., Jacobs, P. A., Maclean, N., and Mantle, D. J. (1964). Abnormalities of the sex chromosome complement in man. Spec. Rep. Ser. med. Res. Coun. (Lond.), No. 305.

28. Craig, A. P., Schteingart, D. E., and Shaw, M. W. (I963). Gonadal dysgenesis with $\mathrm{XO} / \mathrm{XX}$ mosaicism and a positive sex chromatin pattern. F. clin. Endocr., 23, 752.

29. Dantchakoff, V. (1950). La différenciation du sexe chez les vertébrés. Arch. Anat. micr. Morph. exp., 39, 367.

30. Davidson, R. G., Nitowsky, H. M., and Childs, B. (1963). Demonstration of two populations of cells in the human female heterozygous for glucose-6-phosphate dehydrogenase variants. Proc. nat. Acad. Sci. (Wash.), 50, $48 \mathrm{I}$.

31. Gennes, J. L. de, Grouchy, J. de, and Lamy, M. (1963). Dysgénésie gonadique et malformations de type turnérien chez un individu phénotypiquement et chromosomiquement masculin. Sem. Hôp. Paris, 39, 794.

32. Grouchy, J. de (1964). Personal communication.

33. — , Cottin, S., Lamy, M., Netter, A., Netter-Lambert, A., Trévoux, R., and Delzant, G. (1960). Un cas de dysgénésie, gonadique a formule chromosomique male (XY) normale. Rev. franc. Étud. clin. biol., 5, 377.

34. - Josso, N., Gennes, J. L. de, Hennequet, F., Ribier, J., Frézal, J., and Lamy, M. (1963a). Mosaïques intéressant le chromosome $\mathrm{X}$ dans le syndrome de Turner. Sem. Hôp. Paris, 39, 769. 
35. - Klotz, H. P., Massin, J. P., Chimenes, H., and NathanKahn, J. (1962). Un nouveau cas de mosaique $\mathrm{XX} / \mathrm{XO}$ dans un syndrome de Turner. ibid., 38, 3205.

36. - Lamy, M., Aicardi, J., and Pellerin, D. (1963b). Mosaïque $\mathrm{XY} / \mathrm{XO}$ chez un pseudo-hermaphrodite masculin. ibid., 39, 789 .

37. — - — Frezal, J., and Ribier, J. (r96ra). XX/XO mosaics in Turner's syndrome. Lancet, $1,1369$.

38. - $-\longrightarrow$, Yaneva, H., Salomon, Y., and Netter, A. (I96Ib). Further abnormalities of the $X$ chromosome in primary amenorrhoea or in severe oligomenorrhoea. ibid., 2, 777.

39. Chapelle, A. de la (1962). Cytogenetical and clinical observations in female gonadal dysgenesis. Acta endocr. (Kbh.), Suppl. 65 .

40. - - , and Hortling, H. (I962). XO/XY mosaicism. Lancet, 2, 783.

4I. chromosome in a human male. First case. Acta med. scand., Suppl. 412, 25.

42. Dewhurst, C. J., Paine, C. G., and Blank, C. E. (1963). An $\mathrm{XY}$ female with absent gonads and vestigial pelvic organs. f. Obstet. Gynaec. Brit. Cwlth, 70, 675 .

43. Engel, E., and Forbes, A. P. (196I). An abnormal mediumsized metacentric chromosome in a woman with primary gonadal failure. Lancet, 2, 1004.

44. Ferguson-Smith, M. A. Unpublished observations.

45. - (1959). The prepubertal testicular lesion in chromatinpositive Klinefelter's syndrome (Primary micro-orchidism). as seen in mentally handicapped children. Lancet, 1, 219.

46. - (1962). Human cytogenetics and sex determination. In Expanding Goals in Genetics and Psychiatry, ed. F. J. Kallmann, p. 81. Grune and Stratton, New York.

47. - Alexander; D. S., Bowen, P., Goodman, R. M., Kaufmann, B. N., Jones, H. W., and Heller, R. H. (I964a). Clinical and cytogenetical studies in female gonadal dysgenesis and their bearing on the cause of Turner's syndrome. Cytogenetics, 3, 355 .

48. - $\longrightarrow$, and Johnston, A. W. (1960). Chromosome abnormalities in certain diseases of man. Ann. intern. Med., 53, 359.

49. —, Mack, W. S., Ellis, P. M., Dickson, M., Sanger, R., and Race, R. R. (1964b). Parental age and the source of the $X$ chromosomes in XXY Klinefelter's syndrome. Lancet, I 46.

5o. Ferrier, P., Ferrier, S., Klein, D., and Fernex, C. (1963). XY/XO mosaicism. ibid., $\mathbf{1}, 54$.

51. - Gartler, S. M., Waxman, S. H., and Shepard, T. H., II (I962). Abnormal sexual development associated with sex chromosome mosaicism. Pediatrics, 29, 703.

52. - Shepard, TH., Gartler, S., and Burt, B. (196I). Chromatin-positive gonadal dysgenesis and mosaicism. Lancet, $\mathbf{r}$, I 170.

53. Ford, C. E. (1963). The cytogenetics of human intersexuality. In Intersexuality, ed. C. Overzier, p. 86. Academic Press, London and New York.

54. - , and Hamerton, J. L. (1956). The chromosomes of man. Nature (Lond.), 178, 1020.

55. - , Jones, K. W., Polani, P. E., de Almeida, J. C., and Briggs, J. H. (I959). A sex-chromosome anomaly in a case of gonadal dysgenesis (Turner's syndrome). Lancet, 1,711 .

56. Forteza, G., Bonilla, F., Báguena, R., Monmeneu, S., Galbis, M., and Zaragozá, V. (1963). Un caso de mosaicismo XY/ $\mathrm{XX}$ cromatinnegativo, con disgenesia gonadal y sexo fenotipico femenino. Rev. clin. esp., 88, 394.

57. Fraccaro, M., Bott, M. G., Salzano, F. M., Russell, R. W. R., and Cranston, W. I. (I962). Triple chromosomal mosaic in a woman with clinical evidence of masculinisation. Lancet, $\mathbf{1}, 1379$.

58. - Ikkos, D., Lindsten, J., Luft, R., and Tillinger, K. G. (196r). Testicular germinal dysgenesis (male Turner's syndrome). Acta endocr. (Kbh.), 36, 98.

59. Frøland, A., Lykke, A., and Zachau-Christiansen, B. (1963). Ovarian dysgenesis (Turner's syndrome) in the newborn. Acta path. microbiol. scand., 57, 21.

6o. Futterweit, W., Chapman, M. L., Salvaneschi, J. P., and Moloshok, R. E. (196I). Multiple congenital defects in a twelve year old boy with cryptorchidism (male Turner's oyndrome). Metabolism, ro, 1074. 6r. Gagnon, J. Katyk-Longtin, N., and Sinnott, J. C. (1960). Le 믄 syndrome des malformations multiples associé à la dysgénèse gonadique (syndrome de Turner) à formule chromo- : somique XO. Un. méd. Can., 89, 1227.

62. Gartler, S. M., and Sparkes, R. S. (1963). The Lyon-Beutler hypothesis and isochromosome $X$ patients with the Turner $\bar{C}$ syndrome. Lancet, 2, $4 \mathrm{II}$.

63. Giannelli, F. (I963). The pattern of X-chromosome deoxyribonucleic acid synthesis in two women with abnormal sexchromosome complements. ibid., r, 863.

64. Gorman, J. G., Dire, J., Treacy, A. M., and Cahan, A. (1963). The application of $-\mathrm{Xg}^{\mathrm{a}}$ antiserum to the question of red $\mathrm{N}$ cell mosaicism in female heterozygotes. F. Lab. clin. Med., 61, 642.

65. Griboff, S. I., and Lawrence, R. (I96I). The chromosomal etiology of congenital gonadal defects. Amer. F. Med., 30, $\vec{\omega}$ 544 .

66. Haddad, H. M., and Wilkins, L. (I959). Congenital anomalies associated with gonadal aplasia. Pediatrics, 23, 885.

67. Haddad, J. G., Jr. (1962). Turner's syndrome: case reports and review of clinical and cytogenetic aspects. Bull. Tulane N med. Fac., $21,139$.

68. Hamerton, J. L., Jagiello, G. M., and Kirman, B. H. (1962). $\vec{A}$ Sex-chromosome abnormalities in a population of mentally $\mathrm{N}$ defective children. Brit. med. F., 1, 220.

69. Harnden, D. G., and Stewart, J. S. S. (1959). The chromosomes in a case of pure gonadal dysgenesis. ibid., 2, 1285 .

70. Hayward, M. D., and Cameron, A. H. (I96I). Triple mosaicism of the sex chromosomes in Turner's syndrome and Hirschsprung's disease. Lancet, $2,623$.

71. Hemsworth, B. N., and Jackson, H. (1963a). Effect of Busul- $\overrightarrow{0}$ phan on the developing gonad of the male rat. $\mathcal{f}$. Reprod. Fertil., 5, 187. 72. - , and $\frac{\text { (1963b). Effect of Busulphan on the developing }}{\text { ovary in the rat. ibid., 6, } 229 \text {. }}$

73. Hirschhorn, K., Decker, W. H., and Cooper, H. L. (1960). Human intersex with chromosome mosaicism of type XY/XO. New Engl. F. Med., 263, ro44.

74. Hustinx, T. W. J., and Stoelinga, G. B. A. (1964). A ring-X- ู chromosome in part of the somatic cells of a patient with $\mathbb{D}$ some characteristics of the Turner syndrome. Genetica, 35, 1. Q

75. Jacobs, P. A., Harnden, D. G., Buckton, K. E., Court Brown, $\overrightarrow{\bar{O}}$ W. M., King, M. J., McBride, J. A., MacGregor, T. N., 윽 and Maclean, N. (196r). Cytogenetic studies in primary amenorrhoea. Lancet, $\mathrm{I}, \mathrm{I} 183$.

76. Johnston, A. W., Ferguson-Smith, M. A., Handmaker, S. D., Jones, H. W., and Jones, G. S. (I96r). The triple-X syndrome. Clinical, pathological and chromosomal studies in three mentally retarded cases. Brit. med. F., 2, 1046.

77. Jones, H. W., Jr., Ferguson-Smith, M. A., and Heller, R. H. ত (1963). The pathology and cytogenetics of gonadal agenesis. 3 Amer. F. Obstet. Gynec., 87, 578.

78. Josso, N., de Grouchy, J., Frézal, J., and Lamy, M. (1963). 을 Le syndrome de Turner familial. Étude de deux familles $?$ avec caryotypes XO et XX. Sem. Hôp. Paris, 39, 775.

79. Jost, A. (1947). Recherches sur la différenciation sexuelle de 음 l'embryon de lapin. III. Rôle des gonades foetales dans la différenciation sexuelle somatique. Arch. Anat. micr. Morph. 음 exp., 36, 271.

80. - (1958). Embryonic sexual differentiation (morphology, $\mathrm{N}$ physiology, abnormalities. In Hermaphroditism, Genital $\sigma$ Anomalies and Related Endocrine Disorders, ed. H. W. Jones, N Jr., and W. W. Scott, p. I 5. Williams and Wilkins, Baltimore. O

81. Judge, D. L. C., Thompson, J. S., Wilson, D. R., and Thomp- N son, M. W. (1962). XY/XO mosaicism. Lancet, 2, 407.

82. Klevit, H. D., Mellman, W. J., and Eberlein, W. R. (I963). Triple mosaicism with an isochromosome derived from aco partially deleted $\mathrm{Y}$ in a male pseudohermaphrodite. Pedi- $\frac{\mathrm{C}}{(\mathrm{T}}$

atrics, 32, 56 .
83. Klotz, H. P., and Xirau, J. (1962). Un nouveau cas d" “ovaires non fonctionnels". Sem. Hôp. Paris, 38, 3208.

84. Koller, P. C. (1937). The genetical and mechanical properties $\bar{O}$ of sex chromosomes. III. Man. Proc. roy. Soc. Edinb., 57, $\frac{\vec{D}}{\mathrm{~d}}$

85. Lambert, A., and Netter, A. (1962). Pseudo-hermaphrodisme $\frac{\overparen{P}}{\stackrel{\text { 194. }}{Q}}$ male "Turnérien". Sem. Hôp. Paris, 38, 1699. 
86. Lamy, M., de Grouchy, J., Nezeloff, C., Musset, R., and Bellaisch, J. (1963). Dysgénésie gonadique. Phénotype féminin caryotype XY. Rev. franç. Étud. clin. biol., 8, 264.

87. Lemli, L., and Smith, D. W. (1963). The XO syndrome: a study of the differentiated phenotype in 25 patients. 7 . Pediat., 63, 577.

88. Lerner, H. I. (196I). Gonadal dysgenesis diagnosed in infancy. Pediatrics, 28, 508 .

89. Lewis, F. J. W., Mitchell, J. P., and Foss, G. L. (1963). $\mathrm{XY} / \mathrm{XO}$ mosaicism. Lancet, $\mathrm{I}, 22 \mathrm{r}$.

90. Lindsten, J. (1963). The Nature and Origin of $X$ Chromosome Aberrations in Turner's Syndrome. Almqvist Wiksell, Uppsala.

91. - (1964). Personal communication.

92. - - Fraccaro, M., Polani, P. E., Hamerton, J. L., Sanger, R., and Race, R. R. (1963). Evidence that the Xg blood group genes are on the short arm of the $\mathrm{X}$ chromosome. Nature (Lond.), 197, 648.

93. - $\longrightarrow$, and Tillinger, K.-G. (1962). Self-perpetuating ring chromosome in a patient with gonadal dysgenesis. Lancet, $\mathbf{r}$, 593.

94. Lüers, T., Struck, E., and Nevinny-Stickel, J. (1963). Selfperpetuating ring chromosome in gonadal dysgenesis. ibid., 2,887 .

95. Lyon, M. F. (I96I). Gene action in the X-chromosome of the mouse (Mus musculus L.). Nature (Lond.), 190, 372.

96. - (1962). Sex chromatin and gene action in the mammalian X-chromosome. Amer. F. hum. Genet., 14, 135.

97. - (1963a). Attempts to test the inactive-X theory of dosage compensation in mammals. Genet. Res., 4, 93.

98. - (1963b). Personal communication.

99. Maclean, N. (1962). The drumsticks of polymorphonuclear leucocytes in sex-chromosome abnormalities. Lancet, $\mathbf{I}$, II54.

I0o. - Harnden, D. G., Court Brown, W. M., Bond, J., and Mantle, D. J. (1964). Sex-chromosome abnormalities in newborn babies. ibid., 1, 286.

ror. Makino, S., Tonomura, A., Mizutani, M., Sakakura, H., Kumakiri, S., Itoga, S., and Yamafuji, M. (1962). Chromosome studies in five sexually abnormal patients. Proc. fapan. Acad., 38, 31 .

102. Mantle, D. J. (I964). Personal communication.

I03. Mellman, W. J., Klevit, H. D., Yakovac, W. C., Moorhead, P. S., and Saksela, E. S. (1963). XO/XY chromosome mosaicism. F. clin. Endocr., 23, 1090.

104. Mikkelsen, M., Frøland, A., and Ellebjerg, J. (1963). XO/XX mosaicism in a pair of presumably monozygotic twins with different phenotypes. Cytogenetics, 2, 86.

105. Miles, C. P., Luzzatti, L., Storey, S. D., and Peterson, C. D. (1962). A male pseudohermaphrodite with a probable $\mathrm{XO} / \mathrm{XxY}$ mosaicism. Lancet, $2,455$.

106. Miller, O. J., Cooper, H. L., and Hirschhorn, K. (I96I). Recent developments in human cytogenetics. Eugen.Quart., $8,23$.

107. Morishima, A., and Grumbach, M. M. (196r). Karyotypic analysis in a case of Turner's syndrome in a phenotypic male. Amer. F. Dis. Child., 102, 585.

108. Muldal, S., Gilbert, C. W., Laitha, L. G., Lindsten, J., Rowley, J., and Fraccaro, M. (1963). Tritiated thymidine incorporation in an isochromosome for the long arm of the $\mathrm{X}$ chromosome in man. Lancet, $\mathrm{I}, 86 \mathrm{I}$.

ro8a. Ohno, S., Jainchill, J., and Stenius, C. (1963). The creeping vole (Microtus oregani) as a gonosomic mosaic. I. The $\mathrm{OY} / \mathrm{XY}$ constitution of the male. Cytogenetics, 2, 232.

ro9. - - Kaplan, W. D., and Kinosita, R. (1960). On the isopycnotic behaviour of the XX-bivalent in oocytes of Rattus norvegicus. Exp. Cell Res., 19, 637.

I 10. Oikawa, K., and Blizzard, R. M. (I96I). Chromosomal studies of patients with congenital anomalies simulating those of gonadal aplasia. New. Engl. F. Med., 264, roog.

II I. Park, W. W. (1957). The occurrence of sex chromatin in early human and macaque embryos. F. Anat. (Lond.), 91, 369.

I I2. Polani, P. E. (1964). Personal communication.
113. - Hunter, W. F, and Lennox, B. (1954). Chromosomal sex in Turner's syndrome with coarctation of the aorta. Lancet, 2, 120

I 14. Quinodoz, J. M., Ferrier, P., Ferrier, S., Zahnd, G., and Prod'hom, S. (1964). Le syndrome de Turner: a propos de six observations. Helv. med. Acta, 31, 1 .

II 5. Rhode, R. A., and Brager, P. (I963). Personal communication.

II6. Robinson, A., Priest, R. E., and Bigler, P. C. (1964). Male pseudohermaphrodite with $\mathrm{XY} / \mathrm{XO}$ mosaicism and bilateral gonadoblastomas. Lancet, I, I I I.

I 17. Sachs, L. (1954). Sex-linkage and the sex chromosomes in man. Ann. Eugen. (Lond.), 18, 255

I18. Sćhneck, H., Sukoff, M. H., and Sherman, H. H. (I962). Turner's syndrome: review of literature and report of case in newborn infant. N.Y. St. F. Med., 62, 1962.

I19. Schuster, J., and Motulsky, A. G. (1962). Exceptional sexchromatin pattern in male pseudohermaphroditism with $\mathrm{XX} / \mathrm{XY} / \mathrm{XO}$ mosaicism. Lancet, $1,1074$.

I20. Schwarz, G., and Walter, K. (I962). Chromosomal analysis in gonadal dysgenesis with pseudopseudohypoparathyroidism. ibid., I, 1075 .

I2I. Shah, P. N., Naik, S. N., Mahajan, D. K., Dave, M. J., and Paymaster, J. C. (I96I). A new variant of human intersex with discussion on the developmental aspects. Brit. med. F., 2, 474 .

122. Solomon, I. L., Hamm, C. W., and Green, O. C. (1964). Chromosome studies on testicular tissue cultures and blood leukocytes of a male previously reported to have no $\mathrm{Y}$ chromosome. New Engl. F. Med., 271, 586.

123. Sparkes, R. S., and Motulsky, A. G. (I963). Hashimoto's disease in Turner's syndrome with isochromosome $\mathbf{X}$. Lancet, I, 947.

124. Steiker, D. D., Mellman, W. J., Bongiovanni, A. M., Eberlein, W. R., and Leboeuf, G. (196I). Turner's syndrome in the male. F. Pediat., 58, $32 \mathrm{I}$.

125. Stern, C. (1960). Principles of Human Genetics, p. 258. Freeman, San Francisco and London.

126. Therman, E., Patau, K., Smith, D. W., and Demars, R. I (196I). The D Trisomy syndrome and XO gonadal dysgenesis in two sisters. Amer. F. hum. Genet., 13, 193.

127. Tritsch, H., and Schwarz, G. (1963). Germinalzell-Aplasie und Kleinwuchs. Dtsch. med. Wschr., 88, 701 .

128. Turner, H. H. (1938). A syndrome of infantilism, congenital webbed neck, and cubitus valgus. Endocrinology, 23, 566 .

129. - Greenblatt, R. B., and Dominguez, H. (1963). Syndrome of gonadal dysgenesis and abdominal testis with an $\mathrm{XO} / \mathrm{XY}$ chromosome mosaicism. F. clin. Endocr., 23, 709.

130. Turpin, R., Lejeune, J., Lafourcade, J., Chigot, P.-L., and Salmon, C. (196I). Présomption de monozygotisme en dépit d'un dimorphisme sexuel: sujet masculin XY et sujet neutre haplo X. C.R. Acad. Sci. (Paris), 252, 2945.

131. Vaharu, T., Patton, R. G., Voorhess, M. L., and Gardner, L. I. (1961). Gonadal dysplasia and enlarged phallus in a girl with 45 chromosomes plus "fragment". Lancet, I, I35I.

132. Van Wijck, J. A. M., Blankenborg, G. J., and Stolte, L. A. M., (1964). XO/XX mosaicism and mongolism in the same person. ibid., $\mathbf{I}, \mathbf{I} 7 \mathbf{1}$.

133. Warren, J. C., Erkman, B., Cheatum, S., and Holman, G., (1964). Hilus-cell adenoma in a dysgenetic gonad with XX/XO mosaicism. ibid., I, I4I.

134. Waxman, S. H., Gartler, S. M., and Kelley, V. C. (1962) Apparent masculinization of the female fetus diagnosed as true hermaphrodism by chromosomal studies. $\mathcal{F}$. Pediat., 60, 540 .

135. Wilkins, L., and Fleischmann, W. (1944). Ovarian agenesis: pathology, associated clinical symptoms and the bearing on the theories of sex differentiation. F. clin. Endocr., 4, 357.

136. Willemse, C. H. (1962). A patient suffering from Turner's syndrome and acromegaly. Acta endocr. (Kbh.), 39, 204

137. - Van Brink, J. M., and Los, P. L. (1962). XY/XO mosaicism. Lancet, $\mathrm{I}, 488$.

138. Zuelzer, W. W., Beattie, K. M., and Reisman, L. E. (1964). Generalized unbalanced mosaicism attributable to dispermy and probable fertilization of a polar body. Amer. F. hum. Genet., 16, 38. 